\title{
Girdin and Its Phosphorylation Dynamically Regulate Neonatal Vascular Development and Pathological Neovascularization in the Retina
}

\author{
Takanori Ito, ${ }^{*}$ Keiichi Komeima, ${ }^{*}$ Tetsuhiro Yasuma, ${ }^{*}$ Atsushi Enomoto, ${ }^{\dagger}$ Naoya Asai, ${ }^{\dagger}$ Masato Asai, ${ }^{\dagger}$ Sayoko Iwase, ${ }^{*}$ \\ Masahide Takahashi, ${ }^{\dagger}$ and Hiroko Terasaki*
}

\author{
From the Departments of Ophthalmology* and Molecular Pathology, ${ }^{\dagger}$ Nagoya University Graduate School of Medicine, Nagoya, Japan
}

CME Accreditation Statement: This activity ("ASIP 2013 AJP CME Program in Pathogenesis") has been planned and implemented in accordance with the Essential Areas and policies of the Accreditation Council for Continuing Medical Education (ACCME) through the joint sponsorship of the American Society for Clinical Pathology (ASCP) and the American Society for Investigative Pathology (ASIP). ASCP is accredited by the ACCME to provide continuing medical education for physicians.

The ASCP designates this journal-based CME activity (“ASIP 2013 AJP CME Program in Pathogenesis") for a maximum of 48 AMA PRA Category 1 Credit(s) ${ }^{\mathrm{TM}}$. Physicians should only claim credit commensurate with the extent of their participation in the activity.

CME Disclosures: The authors of this article and the planning committee members and staff have no relevant financial relationships with commercial interests to disclose.

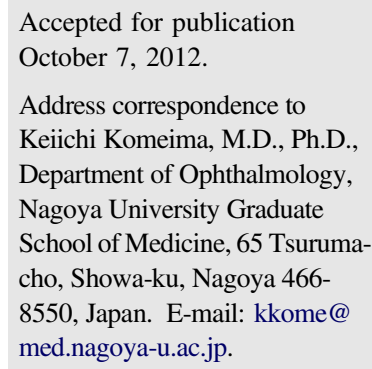

Address correspondence to Keiichi Komeima, M.D., Ph.D., Department of Ophthalmology, Nagoya University Graduate School of Medicine, 65 Tsurumacho, Showa-ku, Nagoya 4668550, Japan. E-mail: kkome@ med.nagoya-u.ac.jp.

\begin{abstract}
Vascular endothelial growth factor (VEGF) is recognized as a principal mediator of vessel growth. VEGF regulates various endothelial cellular processes, including cell migration, proliferation, and survival, through the serine threonine protein kinase Akt. The Akt substrate girdin, an actin-binding protein, is known to regulate VEGF-mediated postnatal angiogenesis. However, the role of girdin and its phosphorylation in neonatal retinal vascular development and ocular pathological neovascularization in vivo has not been elucidated. In the present study, therefore, we investigated these processes using Girdin $^{+/-}$ mice lacking one copy of the girdin gene and girdin S1416A knockin (Girdin-KI ${ }^{S A / S A}$ ) mice in which the phosphorylation site of girdin is completely disrupted. We used three mouse models of pathological ocular neovascularization: oxygen-induced retinopathy (a mouse model of ischemic retinopathies), laserinduced choroidal neovascularization, and a human VEGF transgenic mouse that overexpresses human VEGF specifically in photoreceptor cells and generates pathological neovascularization in the retina. Neonatal vascular development was delayed and pathological neovascularization was decreased in both Girdin $^{+/-}$mice and Girdin-KI $I^{S A / S A}$ mice. These results demonstrate that girdin and its phosphorylation play an important role in neonatal vascular development and in pathological neovascularization in the retina. (Am J Pathol 2013, 182: 586-596; http://dx.doi.org/10.1016/j.ajpath.2012.10.012)
\end{abstract}

Pathological ocular neovascularization is a leading causes of blindness in humans and is found in various eye diseases, including diabetic retinopathy, retinal vein occlusion, retinopathy of prematurity, and age-related macular degeneration (AMD). ${ }^{1-3}$ Over the past decade, our understanding of the molecular mechanisms of angiogenesis has increased at an explosive rate and has led to the approval of antiangiogenic drugs for ocular diseases. ${ }^{4,5}$ Although many patients have benefited from blockers of the angiogenic protein vascular endothelial growth factor (VEGF), limited efficacy and disease recurrence remain a problem. ${ }^{6}$ Therefore, to improve therapeutic outcomes for ocular neovascular diseases,
anti-VEGF agents should be combined with agents that target another molecule.

VEGF signaling affects a number of vital processes during development in adult physiology and pathology, including cancer progression. ${ }^{7,8}$ VEGF denotes a family of five related mammalian growth factors. One family member, VEGF-A, is

Supported by a Grant-in-Aid for Scientific Research from the Japanese Ministry of Education, Culture, Sports, Science and Technology (K.K.), a Grant-in-Aid for Global Center of Excellence Research, Scientific Research (A) (M.T.), and a Grant-in-Aid for Scientific Research on Innovative Areas (M.T.).

T.I., K.K., and T.Y. contributed equally to this work. 
alternatively spliced to generate VEGF-A121, VEGF-A145, VEGF-A165, and VEGF-A189 in humans. ${ }^{9}$ VEGF-A is notably regulated by hypoxia-inducible factor (HIF), which leads to increased expression during tissue growth both in health (embryonic development, wound healing) and disease (cancer, ischemic retinopathy). ${ }^{10}$ In humans, three structurally related VEGF receptor tyrosine kinases (VEGFRs) have been identified: VEGFR-1, VEGFR-2, and VEGFR-3. VEGFR-2 is known to transduce the full range of VEGF responses in endothelial cells, mainly through the PI3K/Akt and ERK pathways. ${ }^{11}$ Akt, or protein kinase $\mathrm{B}$, is a multifunctional serine-threonine protein kinase implicated in a diverse range of endothelial cellular functions, including differentiation, proliferation, migration, and vascular tube formation. ${ }^{12}$ However, the mechanism underlying how Akt regulates such cellular processes has long been a mystery.

In 2005 , Enomoto et $\mathrm{al}^{13}$ identified the Akt-binding protein girdin and demonstrated that girdin is essential for the integrity of the actin cytoskeleton and cell migration and directly links Akt to cell motility. Girdin is a large protein of 1871 amino acids, with a predicted relative molecular mass of 220 $\mathrm{kDa}$, which binds directly to actin filaments through its carboxyl terminal domain. The Akt binding site maps to the carboxyl terminal domain of girdin, and Akt phosphorylates girdin at Ser1416 to regulate its subcellular localization and cell migration in fibroblasts. In 2008, Kitamura et al ${ }^{14}$ revealed that the Akt/girdin signaling pathway is essential to VEGF-mediated neonatal angiogenesis. They found that exogenously delivered adenovirus harboring girdin small interfering RNA (siRNA) in Matrigel (BD Biosciences, San Jose, CA) embedded in mice markedly inhibited VEGFmediated angiogenesis. They also showed that targeted disruption of the girdin gene $(C c d c 88 a)$ in mice impaired vessel remodeling in the neonatal mouse retina and angiogenesis from aortic rings, whereas girdin was dispensable for embryonic vasculogenesis. Girdin is also considered to be a key regulator for cancer progression and pathological neovascularization. ${ }^{15}$ Moreover, girdin is also expressed in the central nervous system and is reported to be associated with postnatal neurogenesis in the dentate gyrus and neuroblast chain migration along the rostral migratory stream. ${ }^{16,17}$

In the present study, we focused on investigating the contribution of the actin-binding protein girdin and its phosphorylation to neonatal vascular development and pathological neovascularization in AMD and in ischemic retinal diseases such as diabetic retinopathy, retinal vein occlusion, and retinopathy of prematurity.

\section{Materials and Methods}

\section{Cell Culture}

Human retinal endothelial cells (HRECs) from Cell Systems (Kirkland, WA) and human umbilical vein endothelial cells (HUVECs) from ATCC (Manassas, VA) were cultured with EGM-2 medium (Lonza, Tokyo, Japan) in an incubator with
$5 \% \mathrm{CO}_{2}$-enriched air. Studies were conducted with cells from passage 4 to 7 .

Quantification of Girdin mRNA Expression in HRECs and HUVECS

Quantitative real-time RT- PCR (RT-qPCR) was performed to measure levels of human girdin mRNA. RNA was isolated from retinas using TRIzol reagent (Invitrogen; Life Technologies, Carlsbad, CA). After quantification of RNA concentration, cDNA was synthesized with a SuperScript first-strand kit (Invitrogen; Life Technologies). RT-qPCR was performed and analyzed using a QuantiTect SYBR Green RT-PCR kit (Qiagen, Valencia, CA) and a LightCycler 2.0 PCR system (Roche Applied Science, Indianapolis, IN). A total volume of $20 \mu \mathrm{L}$ was loaded into LightCycler capillaries, which contained $2 \mu \mathrm{L}$ of cDNA sample and $0.5 \mu \mathrm{mol} / \mathrm{L}$ of primers specific for human girdin (forward: $5^{\prime}$-TGGAGCAGTTCATGACCGC-3'; reverse: 5'-GAGCATGACCTGGTTCAAGAA-3') or human VEGFR2 (forward: 5'-ATCCCTGTGGATCTGAAACG3'; reverse: 5'-CCAAGAACTCCATGCCCTTA-3'). For normalization, human GAPDH was amplified (forward: 5'-GAAGGTGAAGGTCGGAGT-3'; reverse: 5'-GAAGATGGTGATGGGATTTC- $3^{\prime}$ ). Titrations were performed to ensure that PCR reactions were performed in the linear range of amplification. The PCR reaction quality and specificity were verified by melting-curve dissociation analysis. For quantification, a standard curve was generated from a cDNA template for each gene. Relative transcript levels of each gene were calculated using the second-derivative maximum values from the linear regression of cycle number versus log concentration of the amplified gene.

\section{Western Blot Analysis}

Retinas or cultured cells were lysed with radioimmunoprecipitation assay buffer (Pierce; Thermo Fisher Scientific, Rockford, IL). Western blots were performed with anti-girdin (R\&D Systems, Minneapolis, MN) and anti- $\beta$-actin (Cell Signaling Technology, Danvers, MA) antibodies.

\section{Immunohistochemistry of HRECS}

HRECs were fixed in $3.7 \%$ formalin and stained with primary antibodies [anti-girdin, 1:100 (IBL Immuno-Biological Laboratories, Gunma, Japan) and anti- $\beta$-actin, 1:300 (SigmaAldrich, St. Louis, MO)], followed by secondary antibodies [Alexa Fluor 488 goat anti-rabbit IgG and Alexa Fluor 594 goat anti-mouse IgG (Invitrogen; Life Technologies)]. Fluorescence was examined under a $\mathrm{C} 1$ si confocal laser-scanning microscope (Nikon, Tokyo, Japan).

\section{Immunohistochemistry of Mouse Retinas}

The eyes of mice were enucleated at postnatal day 10 (P10) and fixed in $4 \%$ paraformaldehyde overnight. Isolated retinas 
were cut into $50-\mu \mathrm{m}$ sections on a microslicer (VT1200S; Leica Microsystems, Wetzlar, Germany) and immunostained with anti-girdin (1:100) (Abcam, Cambridge, UK) and antiCD31 (1:100) (Dianova, Hamburg, Germany) antibodies. Fluorescence was examined under a fluorescence microscope (Observer Z1; Zeiss, Göttingen, Germany).

\section{LacZ Staining}

The staining procedure was based on the protocol of the Nagy laboratory. ${ }^{18}$ Briefly, mice were perfused with PBS containing $2 \mathrm{mmol} / \mathrm{L} \mathrm{MgCl}_{2}, 0.2 \%$ glutaraldehyde, and $30 \%$ sucrose in PBS, in series. Dissected tissues were soaked in $30 \%$ sucrose in PBS overnight at $4^{\circ} \mathrm{C}$ and in optimal cutting temperature compound (OCT; Sakura Finetek, Tokyo, Japan) for 1 hour at room temperature before freezing at $-80^{\circ} \mathrm{C}$. Frozen tissues were cryosectioned at $10 \mu \mathrm{m}$ and thaw-mounted on Matsunami adhesive silane-coated glass slides (Matsunami Glass, Osaka, Japan). Sections on slides were fixed in PBS containing $2 \mathrm{mmol} / \mathrm{L} \mathrm{MgCl}_{2}$ and $0.2 \%$ glutaraldehyde for 10 minutes, rinsed twice in PBS containing $2 \mathrm{mmol} / \mathrm{L} \mathrm{MgCl}_{2}$, and soaked in LacZ wash buffer (PBS containing $2 \mathrm{mmol} / \mathrm{L}$ $\mathrm{MgCl}_{2}, 0.01 \%$ sodium deoxycholate, and $0.02 \%$ Igepal CA-630 surfactant) twice. Slides were soaked in LacZ staining buffer (Wako Pure Chemical Industries, Osaka, Japan) for 48 hours at room temperature. Stained slides were rinsed in PBS, postfixed in 4\% paraformaldehyde for 10 minutes at $4{ }^{\circ} \mathrm{C}$, counterstained with eosin, and dehydrated with increasing concentrations of ethanol and $100 \%$ xylene. Glass coverslips were mounted with xylene-based medium (Entellan Neu; Merck Millipore, Darmstadt, Germany).

\section{RNA Interference}

siRNA-mediated depletion (knockdown) of girdin was performed. The 21-nucleotide synthetic duplexes were prepared by Qiagen. Cells were transfected with girdin siRNA or a 21-nucleotide control RNA (Qiagen) using Lipofectamine 2000 reagent (Invitrogen; Life Technologies) according to the manufacturer's protocol. For shRNAmediated knockdown of girdin, a set of single-stranded oligonucleotides encoding the girdin target shRNA and its complement was synthesized: 5'-GAAGGAGAGGCAACTGGAT-3' (nt 4166-4184). The oligonucleotide was directed against a sequence selected and provided by Dragon Genomics (Takara Bio, Otsu, Japan). The oligonucleotide pair was annealed and inserted into pcPURU6 $\beta$ (Dragon Genomics) or the pNAMA retroviral shRNA expression vector. To produce retroviral supernatants, GP293 packaging cells were transfected with $24 \mu \mathrm{g}$ of control or girdin shRNA-containing pNAMA vectors, $2 \mu \mathrm{g}$ of pVSVG, and $60 \mu \mathrm{L}$ of Lipofectamine 2000 reagent (Invitrogen; Life Technologies) in 100-mm cell culture dishes containing Opti-MEM medium (Invitrogen; Life Technologies) without fetal bovine serum or antibiotics. The medium was replaced 24 hours later, and virus-containing supernatants were harvested 48 hours after transfection. To infect cells with retrovirus plasmids, $1 \times 10^{5}$ cells were mixed with $3 \mathrm{~mL}$ of viruscontaining supernatant and were seeded in $100-\mathrm{mm}$ cell culture dishes. The supernatant was replaced after 24 hours of incubation. The cell lysates were analyzed by Western blotting using anti-girdin and anti- $\beta$-actin antibodies. Clones in which the expression of girdin was effectively suppressed were selected and used for further study.

\section{Proliferation Assay}

HRECs were starved in serum-free medium, and then $1 \times 10^{4}$ cells were seeded with or without $1 \mu \mathrm{g} / \mathrm{mL}$ VEGF, $50 \mu \mathrm{mol} / \mathrm{L}$ LY294002 (PI3K inhibitor; Merck Millipore), or $1.0 \mathrm{mmol} / \mathrm{L}$ U0126 (ERK inhibitor; Merck Millipore). In the girdin knockdown study, HRECs were cotransfected with either control or girdin siRNA. Transfected cells were starved in serum-free medium, and then $1.25 \times 10^{4}$ cells were seeded with $100 \mathrm{ng} / \mathrm{mL}$ VEGF. After 24 hours of incubation, 3(4,5-dimethylthiazol-2-yl)-2,5'-diphenyltetrazolium bromide (MTT) labeling solution (Cell Proliferation Kit I; Roche Diagnostics, Mannheim, Germany) was added and incubated for 4 hours. Then $10 \%$ SDS solution in $0.1 \mathrm{~mol} / \mathrm{L} \mathrm{HCl}$ was added, and the absorbance was measured at $570 \mathrm{~nm}$.

\section{Migration Assay}

Cell migration assays were performed using the Cultrex 96well cell migration assay kit (Trevigen, Gaithersburg, MD) according to the manufacturer's instructions. In brief, $5 \times 10^{4}$ HRECs were seeded onto polyethylene terephthalate membranes with $8-\mu \mathrm{m}$ pores in the top chambers. In the top and bottom chamber, LY294002 (50 or $200 \mu \mathrm{mol} / \mathrm{L}$ ) or U0126 $(1.0$ or $4.0 \mathrm{mmol} / \mathrm{L})$ were added, and in the bottom chamber, $5 \mathrm{ng} / \mathrm{mL}$ VEGF was added as a chemoattractant. In the girdin knockdown study, HRECs were cotransfected with either control or girdin siRNA, and $1.25 \times 10^{4}$ transfected HRECs were seeded onto the top chamber. In the bottom chamber, $5 \mathrm{ng} / \mathrm{mL}$ VEGF was added as a chemoattractant. After 4 hours of incubation, migrated cells were labeled with Calcein AM (Wako Pure Chemical Industries) solution, and plates were read at $485 \mathrm{~nm}$ (excitation) and $520 \mathrm{~nm}$ (emission).

\section{Tube Formation Assay}

Extracellular matrix gels were prepared with a Chemicon in vitro angiogenesis assay kit (EMD Millipore, Billerica, MA). Gels were solidified over a 96-well microplate, and 30 minutes later, $1 \times 10^{4}$ HRECs were added with $1 \mathrm{ng} / \mathrm{mL}$ VEGF and $50 \mu \mathrm{mol} / \mathrm{L}$ LY294002 or $1.0 \mathrm{mmol} / \mathrm{L}$ U0126. In the girdin knockdown study, HRECs were cotransfected with either control or girdin siRNA. Using this kit, $1.25 \times$ $10^{4}$ HRECs were added onto the surface of gels. After 4 
hours of incubation, tubes were labeled by Calcein-AM solution and photographed.

\section{Animals}

Girdin-deficient Girdin $^{+/-}$and Girdin $^{-/-}$mice were generated as described previously. ${ }^{14}$ Generation of Girdin-KI ${ }^{S A / S A}$ mice has also been described previously in detail. ${ }^{19}$ The Akt phosphorylation site of girdin (Ser1416) was completely disrupted in Girdin- $K I^{S A / S A}$ mice. These mice had normal weight and expressed the same level of girdin protein as wild-type (WT) mice. WT C57BL/6 mice were purchased from the Jackson Laboratory (Bar Harbor, ME). V- $6^{+}$transgenic mice expressing human VEGF through rhodopsin promoter in photoreceptors ( $h V E G F \mathrm{Tg}$ mice) were a generous gift from Peter A. Campochiaro (Johns Hopkins University). These mice demonstrate onset of $h V E G F$ expression at $\mathrm{P} 7$ and, starting at P10, develop sprouts of neovascularization from the deep capillary bed of the retina that grow through the photoreceptor layer and form an extensive network of new vessels in the subretinal space. ${ }^{20}$ All experiments were performed in compliance with Association for Research in Vision and Ophthalmology (ARVO) Statement for the Use of Animals in Ophthalmic and Visual Research and the Nagoya University School of Medicine guidelines for the use of animals.

\section{Quantification of Neonatal Vascular Development in the Retina}

The eyes of mice were enucleated at P5, P7, or P10. The enucleated eyes were fixed in $4 \%$ paraformaldehyde for 2 hours. For flat-mount analyses, four radial incisions were made to relax the eyecups, and the vitreous was carefully removed. The samples were permeabilized for 30 minutes, blocked with $10 \%$ normal goat serum in PBS at room temperature, and incubated with fluorescein isothiocyanateconjugated lectin from Bandeiraea simplicifolia (SigmaAldrich) for 12 hours. Retinal flat mounts were examined under a C1si scanning laser confocal microscope (Nikon), and vascular area was measured.

\section{Mouse Model of OIR}

Oxygen-induced retinopathy (OIR) was induced by exposing mice to $80 \%$ oxygen using an oxygen box with a ProOx 110 controller (BioSpherix, Lacona, NY) from P7 to P12, which resulted in extensive obstruction of the retinal vessels. Returning the mice to room air at P12 triggered outgrowth of pathological retinal neovascularization. To visualize retinal vascular regression, the eyes of mice were enucleated at P12 in the OIR model. Retinal pathological neovascularization and revascularization after hypoxic injury was compared at P17. Enucleated eyes were fixed and treated as described above. Retinal flat mounts were examined under a $\mathrm{C} 1$ si scanning laser confocal microscope (Nikon), and neovascular area or avascular area was measured as described previously. ${ }^{21}$

\section{Mouse Model of Laser-Induced CNV}

To induce choroidal neovascularization (CNV), 5-week-old female mice were anesthetized with $50 \mathrm{mg} / \mathrm{kg}$ Avertin formulation (2,2,2-tribromoethanol-amylene hydrate), and the pupils were dilated with eye drops containing $0.5 \%$ tropicamide and $0.5 \%$ phenylephrine hydrochloride (Mydrin-P; Santen Pharmaceuticals, Osaka, Japan). Three burns of 532-nm diode laser photocoagulation $(75 \mu \mathrm{m}$ spot size, $150 \mathrm{~mW}$ intensity, and $100 \mathrm{~ms}$ duration) were delivered to the retina of each eye using a photocoagulator slit-lamp delivery system and a handheld coverslip as a contact lens. Burns were performed in the three directions of the posterior pole of the retina. Production of a bubble at the time of laser indicates rupture of Bruch's membrane, which is an important factor in obtaining $\mathrm{CNV}$, and so only burns in which a bubble was
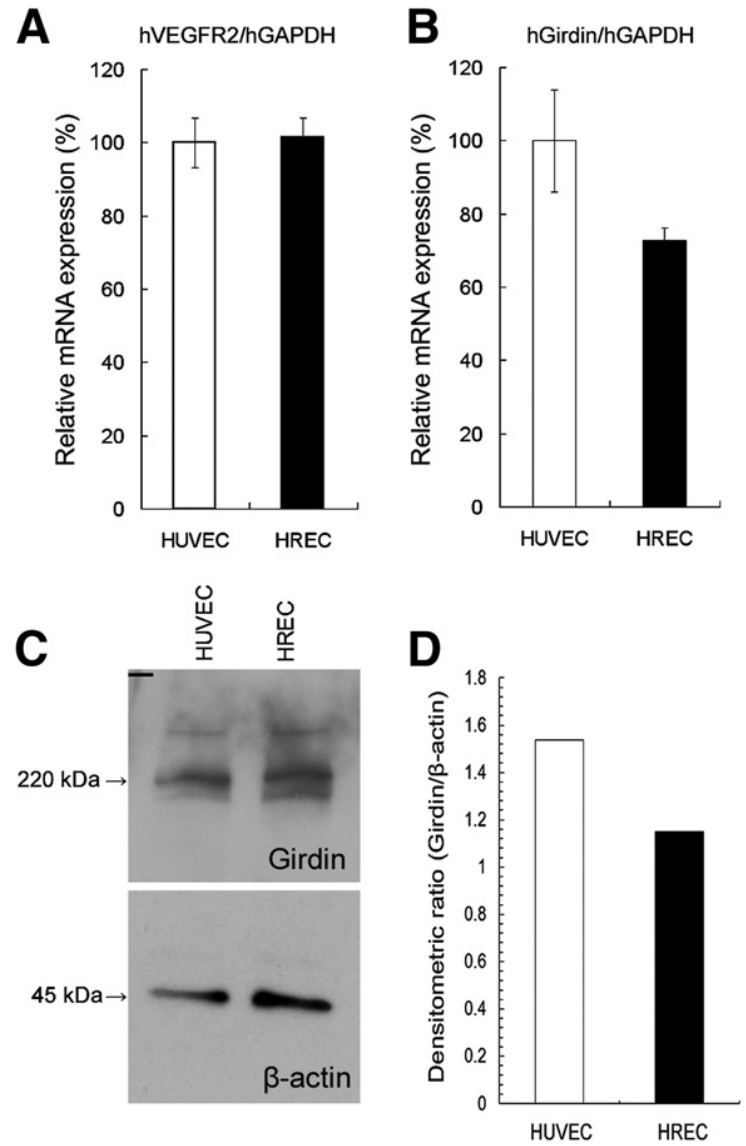

Figure 1 Expression of girdin mRNA and girdin protein in HRECS and HUVECS. A: RT-qPCR analysis indicating relative expression of human VEGFR2 (hVEGFR2) mRNA in HRECs and HUVECs. The ratio of hVEGFR2 mRNA expression in HRECs to that of HUVECS was 1.01. B: RT-qPCR analysis indicating relative expression of human girdin (hGirdin) mRNA in HRECs and HUVECS. The ratio of hGirdin MRNA expression in HRECS to that of HUVECS was 0.727 . Mean values were calculated from three experiments and normalized to the value for HUVECs, which was set at $100 \%$. C: Western blot analysis of cell lysates from HUVECs and HRECs using anti-girdin polyclonal antibody (upper panel) and anti- $\beta$-actin monoclonal antibody (lower panel). D: The amount of anti-girdin immunoreactivity relative to that of anti- $\beta$-actin in the membrane. The ratio of girdin protein expression in HRECS to that of HUVECS was 0.748 . Data are expressed as means \pm SEM. 
produced were included in the present study. For visualization of laser-induced CNV, mice were sacrificed after 1 week, and the complex of vitreous and retina was carefully peeled off the remaining ocular structures. The eyecups were stained with lectin as described above. Retinal and choroidal flat mounts were examined under a $\mathrm{C} 1$ si scanning laser confocal microscope (Nikon), and CNV area was measured as described previously. ${ }^{21}$

\section{Quantification of Retinal Neovascularization in the hVEGF Tg Mouse}

$h V E G F \mathrm{Tg}$ mice were crossed with Girdin-KI ${ }^{S A / S A}$ mice to obtain $h V E G F^{+/-}$Girdin- $K I^{S A / S A}$ mice. The $h V E G F^{+/-}$Girdin$K I^{S A / S A}$ mice were compared with $h V E G F^{+/-}$mice as a control. These mice were sacrificed at P21, to compare intraretinal neovascularization. The eyes were enucleated and fixed, and the vitreous was removed. The eyecups were stained with lectin as described above. The complex of sclera, choroid, and retina was mounted on glass slides and was pressed gently, to visualize intraretinal neovascularization clearly. Intraretinal neovascularization was examined under a fluorescence microscope (BIOREVO BZ-9000; Keyence, Osaka, Japan), and the number of neovascular bulges in each retinal flat mount was counted.

\section{Results}

Expression and Localization of Girdin in HRECs and Mouse Retina

We first examined girdin mRNA and protein expression in HRECs. We performed RT-qPCR and Western blot analysis of both HRECs and HUVECs. The relative expression level of girdin mRNA in HRECs was approximately $73 \%$ of that in HUVECs, whereas VEGFR-2 mRNA was expressed almost equally in HRECs and HUVECs (Figure 1, A and B). Western blot analysis revealed that girdin protein expression in HRECs was also approximately $75 \%$ of that in HUVECs (Figure 1, C and D). In HUVECs, girdin has been reported to localize in actin stress fibers and, to a lesser extent, in peripheral cortical actin filaments. ${ }^{14} \mathrm{We}$ performed immunostaining for HRECs using anti-girdin antibody and found that girdin was partially localized to peripheral cortical actin filaments in the same manner as HUVECs (Figure 2A).

We also investigated localization of girdin in the mouse retina using girdin-deficient $\left(\operatorname{Girdin}^{-\prime}\right)$ mice for LacZ staining and WT mice for immunohistochemistry with antigirdin antibody. As reported previously, in generating girdin-deficient mice, a knockin strain of mice expressing LacZ in place of girdin was established, ${ }^{14}$ and LacZ staining was performed in retinal sections of $\mathrm{Girdin}^{-/-}$mice. LacZ immunostaining suggested that girdin was expressed in endothelial cells, ganglion cells, and some neuronal cells in the inner nuclear layer of the mouse retina (Figure 2B). We

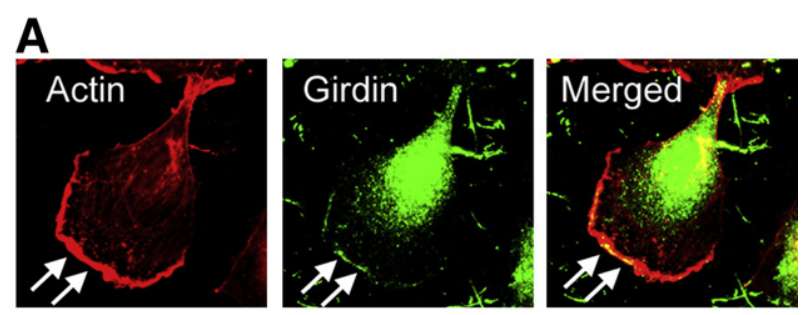

B
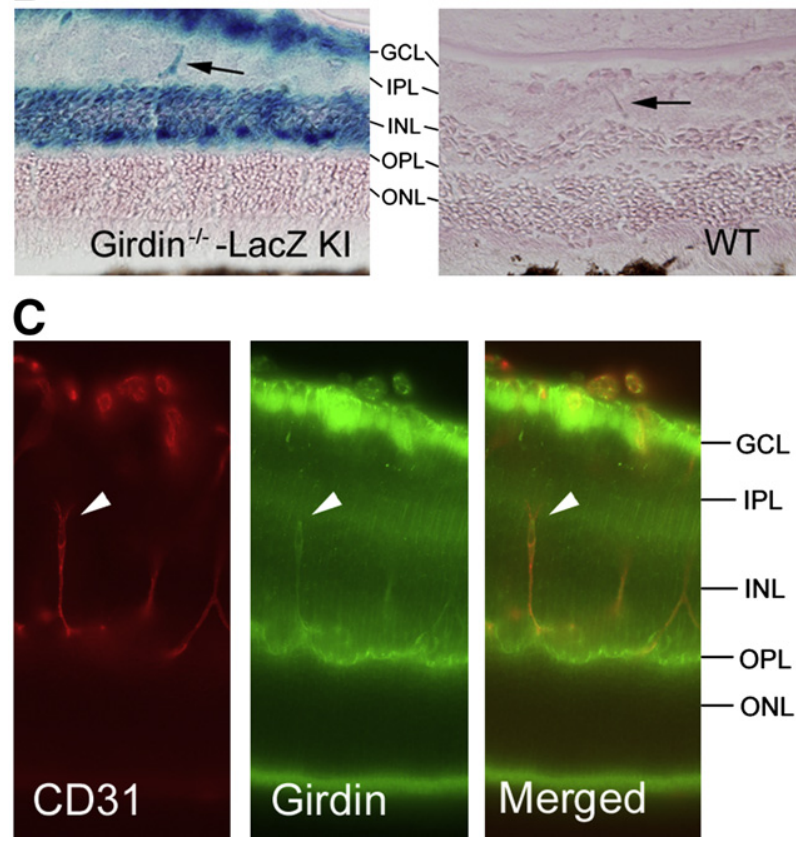

Figure 2 Localization of girdin in HRECs and mouse retinas. A: HRECs were stained with anti- $\beta$-actin monoclonal and anti-girdin polyclonal antibodies. Girdin was expressed in peripheral cortical actin filaments (arrows). B: Retinal sections from a WT and a Girdin $^{-/-}$P12 mouse were stained for LacZ. Sections were counterstained with eosin (red). Bluestained nuclei indicate expression of girdin-LacZ fusion protein containing nuclear localization signal. In $\mathrm{Girdin}^{-/-}$retina, girdin-LacZ-positive cells were present in the ganglion cell layer $(\mathrm{GCL})$, the inner nuclear layer (INL), and a retinal blood vessel (arrow) in the inner plexiform layer (IPL). In WT retina, however, no blue-stained cells were visible in WT retina, including a retinal blood vessel (arrow). C: Retinal sections from a WT P10 mouse were double-stained with anti-girdin and anti-CD31 antibodies. Girdin expression was observed in retinal vessel plexuses and in sprouting tip cells (arrowheads). OPL, outer plexiform layer; ONL, outer nuclear layer. Original magnification, $\times 40(\mathbf{A}) ; \times 10$ (B and C).

also performed immunostaining of WT mouse retina using anti-girdin polyclonal antibody and confirmed that girdin was expressed in retinal vessel plexuses and sprouting tip cells (Figure 2C).

Blockade of the PI3K/Akt Pathway Significantly Inhibits Migration, Proliferation, and Tube Formation of HRECS

We next investigated the effect of PI3K inhibitor LY294002 or ERK inhibitor U0126 on the proliferation, migration, and tube formation of HRECs. MTT assay was performed to quantify HREC proliferation. ${ }^{22}$ Proliferation of HRECs was increased dose dependently by VEGF stimulation and was 

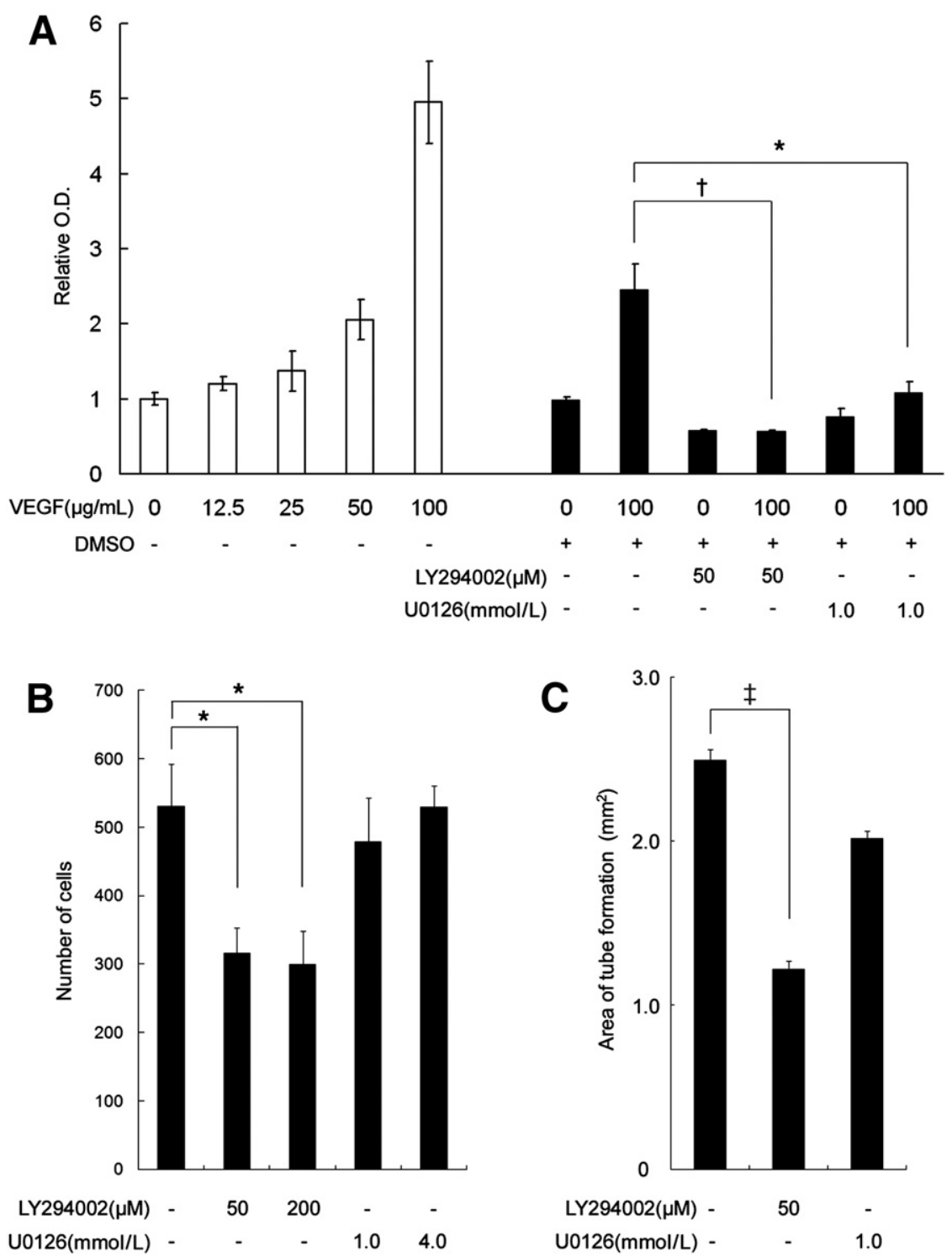

Figure 3 PI3 kinase inhibitor LY294002 reduced migration, tube formation, and proliferation and the ERK inhibitor U0126 reduced proliferation but not migration or tube formation in HRECs stimulated with VEGF. A: MTT assay was performed to quantify HREC proliferation. HRECS proliferated in a VEGF concentration-dependent manner, and $50 \mu \mathrm{mol} / \mathrm{L}$ LY294002 or $1.0 \mathrm{mmol} / \mathrm{L}$ U0126 significantly reduced proliferation of HRECS. B: LY294002 (50 or $200 \mu \mathrm{mol} / \mathrm{L}$ ) significantly reduced migration of HRECs. C: Quantification of the area of tubes formed in assays described in the materials and methods. HRECs were stimulated with $5 \mathrm{ng} / \mathrm{mL}$ VEGF. The capillaries were observed using a confocal microscope, and the total tube areas were quantified using image analysis software (ImageJ version 1.46; NIH, Bethesda, MD). Tube formation of HRECs was significantly reduced by $50 \mu \mathrm{mol} / \mathrm{L}$ LY294002. For representative images of tube formation in each group, see Supplemental Figure S1. Data are expressed as means \pm SEM and represent three independent experiments in each group. $n=3$ wells per group (A and $\mathbf{B}$ ) or 4 wells per group (C). ${ }^{*} P<0.005,{ }^{\dagger} P<0.001$, and ${ }^{\ddagger} P<0.0001$ Student's $t$-test. DMSO, dimethyl sulfoxide; 0.D., optical density. inhibited by $50 \mu \mathrm{mol} / \mathrm{L}$ LY294002 and by $1.0 \mathrm{mmol} / \mathrm{L}$ U0126 when cells were stimulated with $100 \mu \mathrm{g} / \mathrm{mL}$ VEGF (Figure 3A). HREC migration was quantified with modified Boyden chamber assays. Cell migration was significantly inhibited by 50 or $200 \mu \mathrm{mol} / \mathrm{L}$ LY294002, whereas U0126 did not inhibit migration, not even at $4.0 \mathrm{mmol} / \mathrm{L}$, suggesting that the PI3K/Akt pathway is associated with HREC migration (Figure 3B). In the tube formation assay, tube formation of HRECs was significantly impaired by $50 \mu \mathrm{mol} / \mathrm{L}$ LY294002, but was not significantly inhibited by $1.0 \mathrm{mmol} / \mathrm{L} \mathrm{U0126}$ (Figure 3C). Representative images of tube formation with or without LY294002 or U0126 are presented in Supplemental Figure S1.

\section{siRNA-Mediated Girdin Knockdown Impairs Migration and Tube Formation of HRECs}

We also investigated the effect of siRNA-mediated girdin knockdown on the proliferation, migration, and tube formation of HRECs. We first confirmed that girdin was knocked down in girdin siRNA-transfected HRECs, using Western blot analysis (Figure 4A). MTT assay was performed to examine whether siRNA-mediated girdin knockdown affected proliferation of HRECs; however, no significant effect was observed (data not shown). By contrast, HREC migration and tube formation were significantly inhibited in girdin siRNA-transfected HRECs, compared with control (Figure 4, B-D), in response to $5 \mathrm{ng} / \mathrm{mL}$ VEGF-A.

Girdin Deficiency or Disruption of the Phosphorylation Site in Girdin Retards Physiological Neonatal Vascular Development in the Retina in Vivo

To address the potential role of girdin and its phosphorylation on neonatal retinal vascular development in vivo, we quantified vascular area in the retinas of Girdin $^{+/}$mice, Girdin-KI $I^{S A / S A}$ mice, and WT mice at P5, P7, and P10. Western blot analysis revealed that the retinal expression 


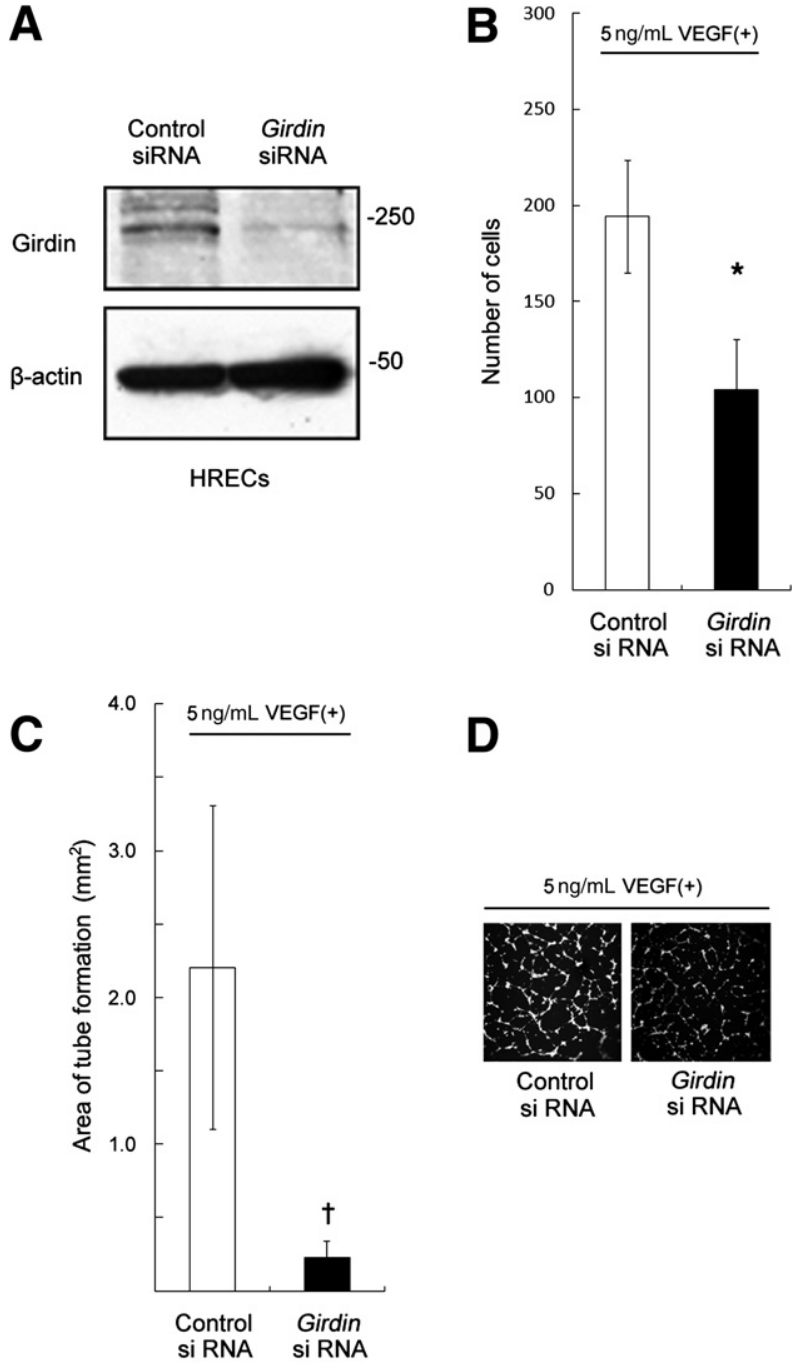

Figure 4 Girdin is essential for VEGF-dependent cell migration and tube formation in HRECs. A: siRNA-mediated knockdown of endogenous girdin in HRECs. The total cell lysates from HRECs transfected with either control or girdin siRNA were analyzed by Western blotting using antigirdin and anti- $\beta$-actin antibodies. B: HRECs were transfected with either control or girdin siRNAs, incubated for 48 hours, and subjected to migration assays in the presence of VEGF-A $(5 \mathrm{ng} / \mathrm{mL})$. Endogenous girdin knockdown significantly reduced migration of HRECs. C: Tube formation by girdin siRNA-transfected cells was significantly impaired in the presence of $5 \mathrm{ng} / \mathrm{mL}$ VEGF-A. D: Representative images of tube formation by HRECs transfected with control siRNA or girdin siRNA in the presence of $5 \mathrm{ng} / \mathrm{mL}$ VEGF-A. Data are expressed as means \pm SEM and represent three independent experiments in each group. ${ }^{*} P<0.05$, ${ }^{\dagger} P<0.001$ Student's $t$-test). $n=3$ wells per group (B) or 4 wells per group (C). Original magnification, $\times 10$ (D).

level of girdin protein in $\mathrm{Girdin}^{+/-}$mice was $48 \%$ of that in WT mice (Supplemental Figure S2). Girdin ${ }^{+/-}$mice were crossed with WT mice, and retinal vascular area was measured in the pups. Vascular area was significantly smaller in Girdin $^{+\prime-}$ mice than in WT mice at P7 and P10 (Figure 5, A and B). Likewise, we compared the retinal vascular area between Girdin- $K I^{S A / S A}$ mice and WT mice and found that retinal vascular development in
Girdin-KI ${ }^{S A / S A}$ mice was significantly retarded at P5, P7, and P10, compared with WT mice (Figure 5, C and D). The weights of Girdin $^{+/-}$mice, Girdin-KI ${ }^{S A / S A}$ mice, and WT mice at sacrifice were not significantly different.

\section{Girdin Deficiency or Disruption of the Phosphorylation Site in Girdin Does Not Affect Vessel Regression But Reduces Ischemic Neovascularization and Revascularization after Ischemic Injury in a Mouse Model of OIR}

We first examined retinal vessel regression due to hyperoxia in Girdin $^{+/-}$mice and Girdin-KI ${ }^{S A / S A}$ mice. Briefly, mice were exposed to $80 \%$ oxygen from P7 to P12 and sacrificed at P12 for measurement of retinal avascular area. The retinal avascular area in Girdin ${ }^{+/}$mice and Girdin$K I^{S A / S A}$ mice did not differ from that in WT mice at P12, which indicated that girdin deficiency or disruption of
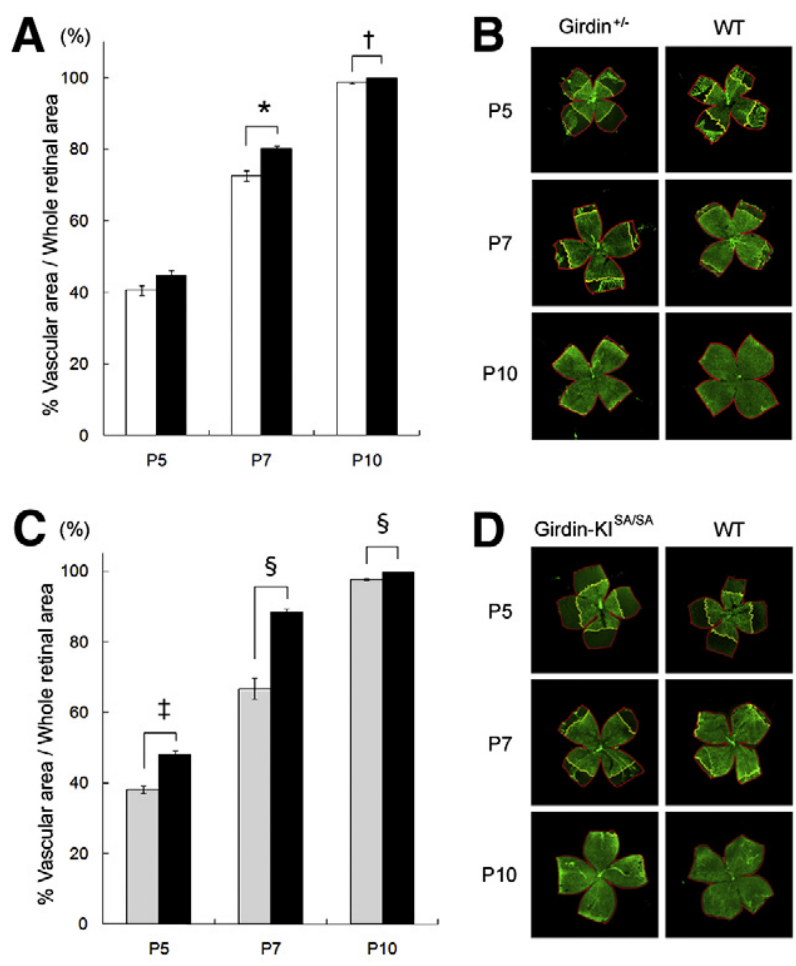

Figure 5 Delay of neonatal retinal vascular development in $\mathrm{Girdin}^{+/-}$ mice or Girdin-KI $I^{S A / S A}$ mice. A: Retinal flat mounts from $\mathrm{Girdin}^{+/-}$mice ( $n=9$ at P5, $n=11$ at P7, $n=9$ at P10) or WT mice ( $n=12$ at P5, $n=10$ at P7, $n=11$ at P10) were stained with fluorescein isothiocyanate-conjugated lectin from Bandeiraea simplicifolia and examined using confocal microscopy. The retinal vascular area in $\mathrm{Girdin}^{+/-}$mice (white bars) at P7 or P10 was significantly smaller than that of agematched WT controls (black bars). B: Representative images of retinal flat mounts in $\mathrm{Girdin}^{+/-}$and WT mice, with edges delineated in red and vascular areas outlined in yellow. C: Retinal flat mounts from Girdin-KI $I^{S A / S A}$ mice $(n=12$ at P5, $n=15$ at P7, $n=18$ at P10) and WT mice ( $n=10$ at $\mathrm{P} 5, n=14$ at P7, $n=19$ at P10) were stained and examined as above. The retinal vascular area in Girdin-KI ${ }^{S A / S A}$ mice (gray bars) at P5, P7, and P10 was significantly smaller than that of age-matched WT controls (black bars). D: Representative images of retinal flat mounts in Girdin-KI ${ }^{S A / S A}$ and WT mice. Data are expressed as means \pm SEM. ${ }^{*} P<0.0005,{ }^{\dagger} P<0.0001$, ${ }^{\ddagger} P<1.0 \times 10^{-5}$, and ${ }^{\S} P<1.0 \times 10^{-6}$ Student's $t$-test. 

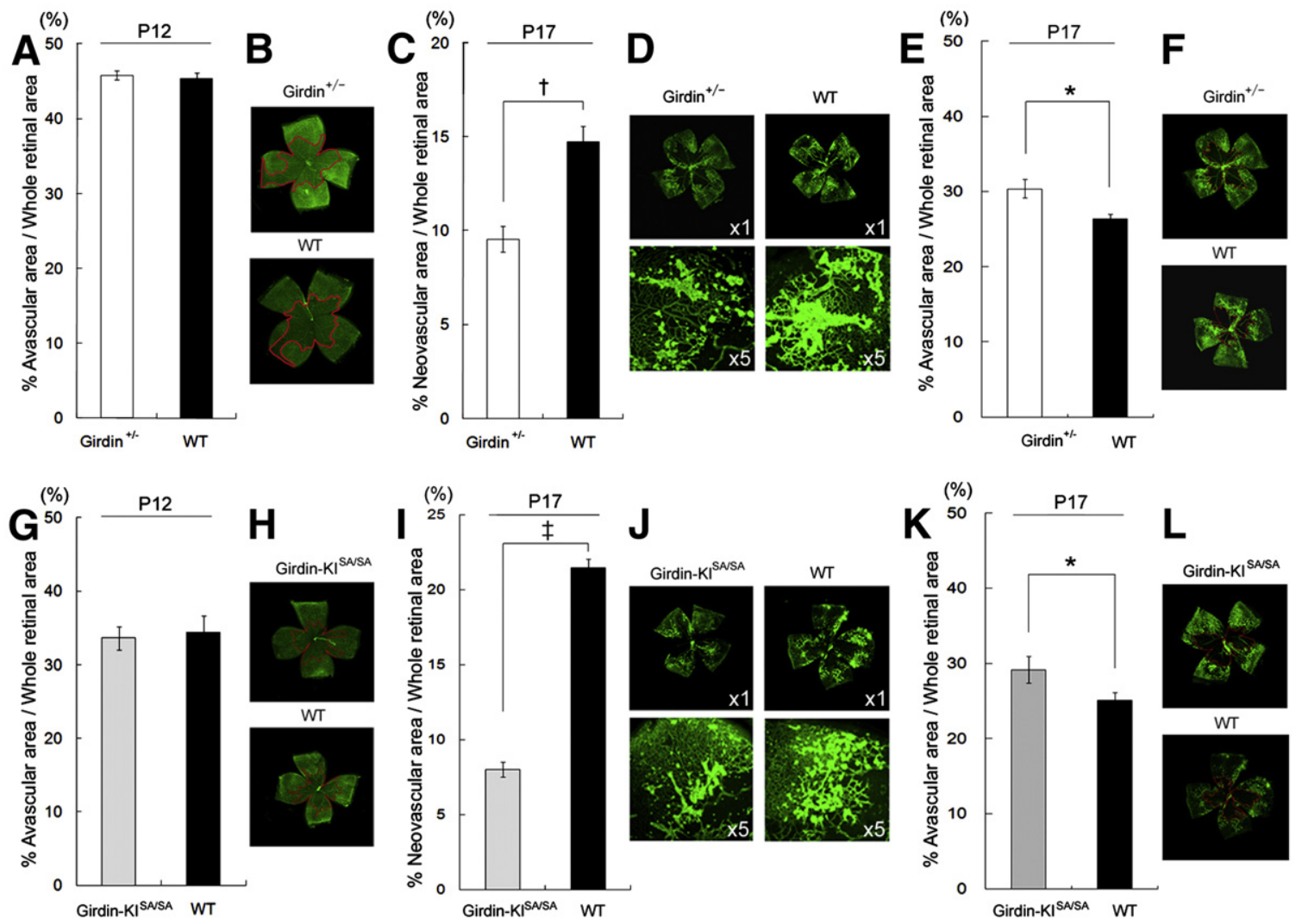

Figure 6 Girdin expression and phosphorylation do not affect vessel regression but promote ischemic neovascularization and revascularization after hypoxic injury in a mouse model of OIR. Mice were exposed to 80\% oxygen from P7 to P12 and were sacrificed at P12 to examine retinal avascular areas caused by vessel regression due to $80 \%$ oxygen. Mice were also sacrificed at P17, to evaluate retinal neovascular areas induced by relative hypoxia or to measure avascular areas for evaluation of revascularization after hypoxic injury. A: Avascular areas in $\operatorname{Girdin}^{+/-}$mice $(n=4)$ did not differ from those of WT controls $(n=7)$ at P12. B: Representative images of retinal flat mounts in $\mathrm{Girdin}^{+/-}$and WT mice, with avascular areas outlined in red. C: The neovascular areas in Girdin $^{+/-}$mice $(n=15)$ were significantly smaller than those of WT mice $(n=14)$ at P17. D: Representative images of retinal flat mounts in Girdin ${ }^{+/-}$and WT mice (top row), with corresponding images at $\times 5$ magnification (bottom row). E: Avascular areas in Girdin ${ }^{+/-}$mice $(n=5)$ were significantly larger at P17 than in WT controls $(n=5)$. F: Representative images of retinal flat mounts in Girdin ${ }^{+/}$and WT mice, with avascular areas outlined in red. G: Avascular areas in Girdin-KI $I^{S A / S A}$ mice $(n=5)$ did not differ from those of WT controls $(n=5)$ at P12. H: Representative images of retinal flat mounts in Girdin-KI $I^{S A / S A}$ and WT mice, with avascular areas outlined in red. I: The neovascular areas of Girdin-KI ${ }^{S A / S A}$ mice $(n=21)$ were significantly smaller than those of WT controls $(n=$ 18) at P17. J: Representative images of retinal flat mounts in Girdin-KI ${ }^{S A / S A}$ and WT mice (top row), with corresponding images at $\times 5$ magnification (bottom row). K: Avascular areas of Girdin-KI $I^{S A / S A}$ mice $(n=6)$ were significantly larger at P17 than those of WT controls $(n=6)$. L: Representative images of retinal flat mounts in Girdin-KI ${ }^{S A / S A}$ and WT mice, with avascular areas outlined in red. Data are expressed as means \pm SEM. ${ }^{*} P<0.05,{ }^{\dagger} P<1.0 \times 10^{-4}$, and ${ }^{\ddagger} P<1.0$ $\times 10^{-18}$, Student's $t$-test.

the girdin phosphorylation site does not affect vessel regression due to hyperoxia in the retina (Figure 6, A, B, $\mathrm{G}$, and $\mathrm{H})$. We next investigated the role of girdin expression and phosphorylation on pathological retinal neovascularization in ischemic retinopathy using a mouse model of OIR. Retinal neovascular area at P17 was significantly smaller in $\mathrm{Girdin}^{+/-}$mice and Girdin-KI $I^{S A / S A}$ mice than in WT mice (Figure 6, C, D, I, and J). We then measured retinal avascular areas at P17 to evaluate revascularization rates after hypoxic injury in $\mathrm{Girdin}^{+/-}$ mice and Girdin-KI $I^{S A / S A}$ mice. Retinal avascular area was significantly larger in Girdin $^{+/-}$mice and Girdin-KI ${ }^{\text {SA/SA }}$ mice than in WT mice (Figure 6, E, F, K, and L). These findings indicated that disruption of girdin expression or its phosphorylation inhibits ischemic neovascularization and revascularization after ischemic injury.
Girdin Deficiency or Disruption of the Phosphorylation Site in Girdin Reduces CNV in a Mouse Model of LaserInduced CNV

$\mathrm{CNV}$ is a defining feature of wet AMD. CNV derives from choroidal rather than retinal vessels and occurs in a completely different manner from retinal neovascularization. Unlike retinal neovascularization, in $\mathrm{CNV}$ ischemia does not appear to be a major stimulus. ${ }^{22}$ Girdin $^{+/-}$mice, Girdin- $K I^{S A / S A}$ mice, and WT mice were subjected to laser photocoagulation. Mouse retinas with rupture of Bruch's membrane were stained with fluorescein isothiocyanate-conjugated lectin and examined using confocal microscopy. The mean area of CNV at sites of Bruch's membrane rupture was significantly smaller in Girdin $^{+/-}$mice and Girdin-KI $I^{\text {SA/SA }}$ mice than in WT mice (Figure 7). 


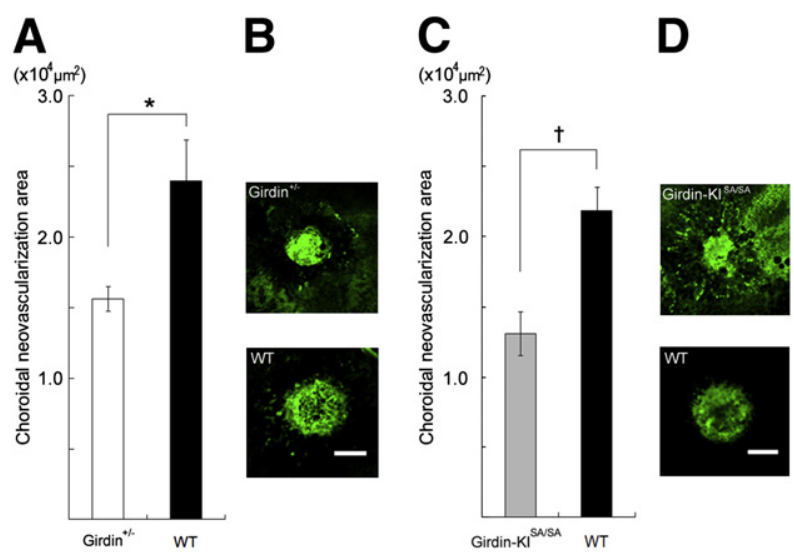

Figure 7 Reduction of CNV in Girdin ${ }^{+/-}$mice and Girdin-KI ${ }^{S A / S A}$ mice in a mouse model of laser-induced CNV. After treatment by laser, adult Girdin $^{+/-}$mice, Girdin-KI $I^{S A / S A}$ mice, and WT controls demonstrated rupture of Bruch's membrane at three locations in each eye. After 7 days, retinal and choroidal flat mounts were stained with fluorescein isothiocyanateconjugated lectin from Bandeiraea simplicifolia and examined using confocal microscopy. A: Image analysis confirmed that the area of CNV was significantly smaller in Girdin ${ }^{+/-}$mice $(n=17)$ than in WT mice $(n=15)$. B: Representative confocal microscopic images of CNVs in a $\mathrm{Girdin}^{+/-}$ mouse and a WT control. C: The area of CNV was significantly smaller in Girdin-KI ${ }^{S A / S A}$ mice $(n=16)$ than in WT controls $(n=18)$. D: Representative confocal microscopic images of CNVs in a Girdin-KISA/SA mouse and a WT control. Data are expressed as means \pm SEM. ${ }^{*} P<0.01,{ }^{\dagger} P<0.001$ Student's $t$-test. Scale bar $=100 \mu \mathrm{m}$.

\section{Disruption of the Phosphorylation Site in Girdin Reduces Pathological Retinal Neovascularization Caused by VEGF Overexpression in Photoreceptors}

We investigated the effect of blockade of girdin phosphorylation using transgenic mice in which the rhodopsin promoter drives expression of human VEGF in photoreceptors ( $h V E G F \mathrm{Tg}$ mice) ${ }^{20} \mathrm{We}$ crossed $h V E G F \mathrm{Tg}$ mice with Girdin- $K I^{S A / S A}$ mice to generate $h V E G F^{+/}$Girdin$K I^{S A / S A}$ mice. Retinal neovascularization was localized to the photoreceptor layer and outer nuclear layer in the $h V E G F \mathrm{Tg}$ mice, and to the inner surface of the retina in the OIR mice (Figure 8A). The number of neovascular tufts in retinas of P21 $h V E G F^{+/}$Girdin-KISA/SA mice was significantly lower than in $h V E G F^{+/-}$mice (Figure $8, \mathrm{~B}$ and C).

\section{Discussion}

Girdin is expressed at the leading edge of migrating HUVECs and Akt-mediated phosphorylation of girdin promotes VEGFdependent migration and tube formation by these cells. ${ }^{14}$ In the present study, girdin mRNA and protein in HRECs were expressed at approximately $70 \%$ of the level observed in HUVECs, and girdin was expressed in the leading edge of HRECs and retinal vessels in vivo. Furthermore, VEGFstimulated proliferation, migration, and tube formation of HRECs were inhibited by a PI3K inhibitor, LY294002, which suggests that VEGF-dependent cell proliferation, migration, and tube formation in HRECs are associated with the PI3
kinase-Akt signaling pathway. Furthermore, VEGF-stimulated migration and tube formation of girdin siRNA-transfected HRECs were significantly impaired, but VEGF-stimulated proliferation was not impaired. These findings are consistent with a previous study in HUVECs ${ }^{14}$ and suggest that girdin is critical for VEGF-mediated migration and tube formation of HRECs, rather than for their proliferation.

Developmental retinal vascularization begins in the innermost retinal layers at the optic nerve head and radiates outward from this central point. It reaches the retinal periphery just before birth in humans and during the first postnatal week in mice. Additional capillary networks in outer retinal layers then arise by sprouting from the nascent inner vascular layer. ${ }^{23,24}$ Kitamura et $\mathrm{al}^{14}$ reported that neonatal Girdin $^{-/-}$mice displayed weight loss after P7 to P8 and died by P25 and that the retinal vascular area of $\mathrm{Girdin}^{-1-}$ mice was approximately $60 \%$ of that in WT, with incomplete coverage at the retinal periphery at P3 and P7; however, they did not detect any delay of retinal vascular

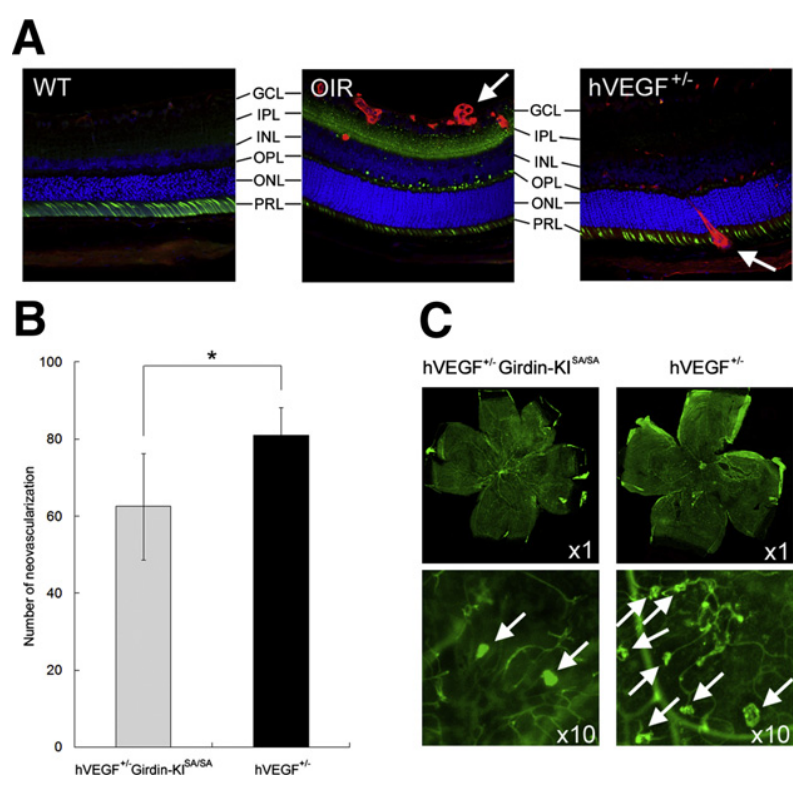

Figure 8 Reduction of pathological neovascularization caused by VEGF overexpression in Girdin-KI ${ }^{S A / S A}$ mouse retinas. A: Retinal sections stained with lectin from Bandeiraea simplicifolia (red) show pathological neovascularization in the retina of a mouse model of OIR or a human VEGF transgenic mouse ( $h \mathrm{VEGF}^{+/-}$mouse). Retinal sections are counterstained with peanut agglutinin (green) and DAPI (blue) to show the cell layers, including the ganglion cell layer (GCL), inner plexiform layer (IPL), inner nuclear layer (INL), outer plexiform layer (OPL), outer nuclear layer (ONL), and photoreceptor layer (PRL). Pathological neovascularization in $h \mathrm{VEGF}^{+/}$- mice (right panel) was present in the $0 \mathrm{NL}$, PRL, retinal pigmented epithelium, and choroid (arrow), whereas that in OIR mice (middle panel) was present on the surface of the inner retina (arrow). B: Human VEGF was overexpressed in mouse retinas in Girdin-KI $I^{S A / S A}$ mice and WT mice crossed with $h V E G F T g$ mice. Mice were sacrificed at P21, and neovascular tufts in the retina and choroid were counted under a fluorescent microscope. The number of pathological neovascular tufts in the retina and choroid in $h V E G F^{+/-}$Girdin-KI $I^{S A / S A}$ mice was significantly smaller than in $h V E G F^{+/-}$controls. C: Representative images of retinal and choroidal flat mounts of $h V E G F^{+/-}$Girdin-KI $I^{S A / S A}$ mice and $h V E G F^{+/-}$controls (top row). In corresponding images at $\times 10$ magnification (bottom row), neovascular tufts are indicated by arrows. Data are expressed as means \pm SEM. $n=12$ mice per group. ${ }^{*} P<0.05, U$-test. 
development in Girdin $^{+/-}$mice. In the present study, we considered that the effect of girdin deficiency on neonatal vascular development might not be accurately evaluated in Girdin $^{+/-}$mice, because the expression level of girdin in the retina of a Girdin $^{+-}$mouse was at most $50 \%$ of that in WT mice. We therefore repeated this experiment using a greater number of irdin $^{+/-}$mice than in the previous study.

We first demonstrated that girdin protein expression in the Girdin $^{+/-}$mouse retina was approximately $50 \%$ of that in WT mice, which indicated that $\operatorname{Girdin}^{+/-}$mice can be used as a model of girdin deficiency. The vascular area in Girdin ${ }^{+\prime-}$ mice was significantly smaller than that in WT mice at P7 and P10, which elucidated that girdin deficiency retarded neonatal retinal vascular development. To evaluate the contribution of the catalytic activity of girdin to neonatal vascular development in vivo, we used a Girdin-KI $I^{S A / S A}$ mouse with a knockin point mutation at the girdin phosphorylation site. A Ser-toAla mutant girdin protein (S185A) was generated to abolish its phosphorylation. ${ }^{19}$ Vascular development was also significantly retarded in Girdin-KI ${ }^{S A / S A}$ mice, compared with WT mice, at P5, P7, and P10. The differences between control and mutant mice at P10 were very small, however, which is thought to reflect a catch-up phenomenon in the mutant mice. These results indicated that girdin expression and its phosphorylation were associated with neonatal retinal vascular development in vivo.

Pathological neovascularization also occurs in the retina and is a major feature of common blinding diseases, such as retinopathy of prematurity, diabetic retinopathy, and AMD. ${ }^{25}$ The mouse model of OIR allows an evaluation of the role of specific molecules in ischemic proliferative retinopathies, including diabetic retinopathy, retinal vein occlusion, and retinopathy of prematurity. In the OIR model, relative hypoxia after the exposure of mice to hyperoxia $(80 \%$ oxygen) and return to normoxia (20\% oxygen) stimulates VEGF production to induce new vessels. This induction results in the migration and proliferation of retinal vascular endothelial cells and the formation of pathological vascular tufts, potentially leading to temporary or permanent blindness. ${ }^{20}$ Immediately after exposure to hyperoxia in the OIR model, whole mounts of retinas from Girdin $^{+/-}$mice, Girdin$K I^{S A / S A}$ mice, and WT controls displayed central avascular areas of approximately similar size. These findings indicated that girdin and its phosphorylation are not associated with vascular regression caused by high oxygen levels, and simultaneously indicated that the situation at the onset of pathological revascularization caused by relative hypoxia after transfer of mice to room air (P12) was similar in these three lines of mice. However, in Girdin ${ }^{+/-}$and Girdin- $K I^{S A / S A}$ mice, the process of revascularization after ischemic injury was significantly delayed, compared with WT mice, at P17 in the OIR model. Thus, girdin and its phosphorylation appear to have a critical role in the generation of new capillaries that intrude into the central avascular area after vascular regression. Pathological neovascular tufts at P17 were also significantly decreased in $\operatorname{Girdin}^{+/-}$and Girdin-KI ${ }^{S A / S A}$ mice, which indicates that girdin and its phosphorylation by Akt facilitate retinal angiogenesis with respect to both capillary generation and neovascular tuft formation.

$\mathrm{CNV}$ occurs in diseases that involve abnormalities of the retinal pigmented epithelium and Bruch's membrane, such as AMD. Rupturing Bruch's membrane with laser photocoagulation in mice serves as a good model for CNV. ${ }^{26,27}$ The reduction in CNV in Girdin ${ }^{+/-}$mice and Girdin-KI ${ }^{S A / S A}$ mice suggests that girdin and its phosphorylation contribute to neovascularization triggered by stimuli other than ischemia. In the CNV model described above, VEGF has been implicated as a critical stimulus, because VEGF expression occurs in combination with the development of $\mathrm{CNV}$ and because VEGF antagonist powerfully suppresses $\mathrm{CNV} .{ }^{28}$ In fact, intravitreous injection of a VEGF antagonist (bevacizumab or ranibizumab) has been effective for treating $\mathrm{CNV}$ in patients with neovascular AMD. ${ }^{29}$

In 1997, Okamoto et $\mathrm{al}^{20}$ first generated $h V E G F$ Tg mice that overexpress human VEGF-A in photoreceptor cells and develop progressive subretinal neovascularization and therefore have a phenotype similar to that seen in patients in neovascular AMD. We obtained $\mathrm{V}-6^{+}$mice, a $h V E G F$ Tg mouse line that demonstrates focal areas of intraretinal or subretinal neovascularization at 1 month of age (Figure 8A), and crossed them with Girdin- $K I^{S A / S A}$ mice to generate $h V E G F^{+/}$Girdin$K I^{S A / S A}$ mice. Retinal neovascularization in $h V E G F^{+/-}$Girdin$K I^{S A / S A}$ mice was significantly decreased, compared with $h V E G F^{+/-}$mice. These results strongly suggest that girdin phosphorylation functions downstream of VEGF signaling and promotes pathological retinal neovascularization in vivo.

To our knowledge, the present study is the first to demonstrate that girdin expression and phosphorylation regulate neonatal vascular development and pathological neovascularization in the retina in vivo. Collectively, these results suggest that girdin may be a good target for treatment of pathological retinal neovascularization, which has a critical role in the pathogenesis of a variety of retinal diseases, including diabetic retinopathy, retinal vein occlusion, retinopathy of prematurity, and AMD.

\section{Acknowledgments}

We thank Noboru Ogiso, Yasutaka Ohya, and Kumiko Yano (Nagoya University, Japan) for mouse embryo transfer and animal care.

\section{Supplemental Data}

Supplemental material for this article can be found at http://dx.doi.org/10.1016/j.ajpath.2012.10.012.

\section{References}

1. Bradley J, Ju M, Robinson GS: Combination therapy for the treatment of ocular neovascularization. Angiogenesis 2007, 10:141-148 
2. Chen J, Smith LE: Retinopathy of prematurity. Angiogenesis 2007, 10 $133-140$

3. Friedlander M, Dorrell MI, Ritter MR, Marchetti V, Moreno SK, El-Kalay M, Bird AC, Banin E, Aguilar E: Progenitor cells and retinal angiogenesis. Angiogenesis 2007, 10:89-101

4. Gragoudas ES, Adamis AP, Cunningham ET Jr, Feinsod M, Guyer DR; VEGF Inhibition Study in Ocular Neovascularization Clinical Trial Group: Pegaptanib for neovascular age-related macular degeneration. N Engl J Med 2004, 351:2805-2816

5. Ferrara N, Damico L, Shams N, Lowman H, Kim R: Development of ranibizumab, an anti-vascular endothelial growth factor antigen binding fragment, as therapy for neovascular age-related macular degeneration. Retina 2006, 26:859-870

6. Carmeliet P, Jain RK: Molecular mechanisms and clinical applications of angiogenesis. Nature 2011, 473:298-307

7. Olsson AK, Dimberg A, Kreuger J, Claesson-Welsh L: VEGF receptor signalling-in control of vascular function. Nat Rev Mol Cell Biol 2006, 7:359-371

8. Bergers G, Hanahan D: Modes of resistance to anti-angiogenic therapy. Nat Rev Cancer 2008, 8:592-603

9. Koch S, Tugues S, Li X, Gualandi L, Claesson-Welsh L: Signal transduction by vascular endothelial growth factor receptors. Biochem J 2011, 437:169-183

10. Fong GH: Regulation of angiogenesis by oxygen sensing mechanisms. J Mol Med (Berl) 2009, 87:549-560

11. Zachary I: VEGF signalling: integration and multi-tasking in endothelial cell biology. Biochem Soc Trans 2003, 31:1171-1177

12. Ackah E, Yu J, Zoellner S, Iwakiri Y, Skurk C, Shibata R, Ouchi N, Easton RM, Galasso G, Birnbaum MJ, Walsh K, Sessa WC: Akt1/protein kinase Balpha is critical for ischemic and VEGF-mediated angiogenesis. J Clin Invest 2005, 115:2119-2127

13. Enomoto A, Murakami H, Asai N, Morone N, Watanabe T, Kawai K, Murakumo Y, Usukura J, Kaibuchi K, Takahashi M: Akt/PKB regulates actin organization and cell motility via Girdin/APE. Dev Cell 2005, 9:389-402

14. Kitamura T, Asai N, Enomoto A, Maeda K, Kato T, Ishida M, Jiang P, Watanabe T, Usukura J, Kondo T, Costantini F, Murohara T, Takahashi M: Regulation of VEGF-mediated angiogenesis by the Akt/PKB substrate Girdin. Nat Cell Biol 2008, 10:329-337

15. Weng L, Enomoto A, Ishida-Takagishi M, Asai N, Takahashi M: Girding for migratory cues: roles of the Akt substrate Girdin in cancer progression and angiogenesis. Cancer Sci 2010, 101: 836-842

16. Enomoto A, Asai N, Namba T, Wang Y, Kato T, Tanaka M, Tatsumi H, Taya S, Tsuboi D, Kuroda K, Kaneko N, Sawamoto K, Miyamoto R, Jijiwa M, Murakumo Y, Sokabe M, Seki T, Kaibuchi K, Takahashi M: Roles of disrupted-in-schizophrenia 1-interacting protein girdin in postnatal development of the dentate gyrus. Neuron 2009, 63 : 774-787
17. Wang Y, Kaneko N, Asai N, Enomoto A, Isotani-Sakakibara M, Kato T, Asai M, Murakumo Y, Ota H, Hikita T, Namba T, Kuroda K, Kaibuchi K, Ming GL, Song H, Sawamoto K, Takahashi M: Girdin is an intrinsic regulator of neuroblast chain migration in the rostral migratory stream of the postnatal brain. J Neurosci 2011, 31: 8109-8122

18. Lobe CG, Koop KE, Kreppner W, Lomeli H, Gertsenstein M, Nagy A: Z/AP, a double reporter for Cre-mediated recombination. Dev Biol 1999, 208:281-292

19. Miyake H, Maeda K, Asai N, Shibata R, Ichimiya H, IsotaniSakakibara M, Yamamura Y, Kato K, Enomoto A, Takahashi M, Murohara T: The actin-binding protein Girdin and its Akt-mediated phosphorylation regulate neointima formation after vascular injury. Circ Res 2011, 108:1170-1179

20. Okamoto N, Tobe T, Hackett SF, Ozaki H, Vinores MA, LaRochelle W, Zack DJ, Campochiaro PA: Transgenic mice with increased expression of vascular endothelial growth factor in the retina: a new model of intraretinal and subretinal neovascularization. Am J Pathol 1997, 151:281-291

21. Guaiquil V, Swendeman S, Yoshida T, Chavala S, Campochiaro PA, Blobel CP: ADAM9 is involved in pathological retinal neovascularization. Mol Cell Biol 2009, 29:2694-2703

22. Schomber T, Kopfstein L, Djonov V, Albrecht I, Baeriswyl V, Strittmatter K, Christofori G: Placental growth factor-1 attenuates vascular endothelial growth factor-A-dependent tumor angiogenesis during beta cell carcinogenesis. Cancer Res 2007, 67:10840-10848

23. Michaelson IC: The mode of development of the vascular system of the retina, with some observations on its significance for certain retinal diseases. Trans Ophthalmol Soc UK 1948, 68:137-180

24. Connolly SE, Hores TA, Smith LE, D'Amore PA: Characterization of vascular development in the mouse retina. Microvasc Res 1988, 36: 275-290

25. Gariano RF, Gardner TW: Retinal angiogenesis in development and disease. Nature 2005, 438:960-966

26. Miki K, Miki A, Matsuoka M, Muramatsu D, Hackett SF, Campochiaro PA: Effects of intraocular ranibizumab and bevacizumab in transgenic mice expressing human vascular endothelial growth factor. Ophthalmology 2009, 116:1748-1754

27. Yi X, Ogata N, Komada M, Yamamoto C, Takahashi K, Omori K, Uyama M: Vascular endothelial growth factor expression in choroidal neovascularization in rats. Graefes Arch Clin Exp Ophthalmol 1997, 235:313-319

28. Kwak N, Okamoto N, Wood JM, Campochiaro PA: VEGF is major stimulator in model of choroidal neovascularization. Invest Ophthalmol Vis Sci 2000, 41:3158-3164

29. Avery RL, Pieramici DJ, Rabena MD, Castellarin AA, Nasir MA, Giust MJ: Intravitreal bevacizumab (Avastin) for neovascular age-related macular degeneration. Ophthalmology 2006, 113. 363-372.e5 